University of Nebraska - Lincoln

DigitalCommons@University of Nebraska - Lincoln

\title{
Glyphosate, Other Herbicides, And Transformation Products In Midwestern Streams, 2002
}

William A. Battaglin

U.S. Geological Survey, wbattagl@usgs.gov

Dana W. Kolpin

U.S. Geological Survey, dwkolpin@usgs.gov

Elizabeth A. Scribner

U.S. Geological Survey, scribner@usgs.gov

Kathryn M. Kuivila

U.S. Geological Survey, kkuivila@usgs.gov

Mark W. Sandstrom

U.S. Geological Survey, sandstro@usgs.gov

Follow this and additional works at: https://digitalcommons.unl.edu/usgsstaffpub

Battaglin, William A.; Kolpin, Dana W.; Scribner, Elizabeth A.; Kuivila, Kathryn M.; and Sandstrom, Mark W., "Glyphosate, Other Herbicides, And Transformation Products In Midwestern Streams, 2002" (2005). USGS Staff -- Published Research. 599.

https://digitalcommons.unl.edu/usgsstaffpub/599

This Article is brought to you for free and open access by the US Geological Survey at DigitalCommons@University of Nebraska - Lincoln. It has been accepted for inclusion in USGS Staff -- Published Research by an authorized administrator of DigitalCommons@University of Nebraska - Lincoln. 


\title{
GLYPHOSATE, OTHER HERBICIDES, AND TRANSFORMATION PRODUCTS IN MIDWESTERN STREAMS, 2002 ${ }^{1}$
}

\author{
William A. Battaglin, Dana W. Kolpin, Elizabeth A. Scribner, \\ Kathryn M. Kuivila, and Mark W. Sandstrom ${ }^{2}$
}

ABSTRACT: The use of glyphosate has increased rapidly, and there is limited understanding of its environmental fate. The objective of this study was to document the occurrence of glyphosate and the transformation product aminomethylphosphonic acid (AMPA) in Midwestern streams and to compare their occurrence with that of more commonly measured herbicides such as acetochlor, atrazine, and metolachlor. Water samples were collected at sites on 51 streams in nine Midwestern states in 2002 during three runoff events: after the application of pre-emergence herbicides, after the application of post-emergence herbicides, and during harvest season. All samples were analyzed for glyphosate and 20 other herbicides using gas chromatography/mass spectrometry or high performance liquid chromatography/mass spectrometry. The frequency of glyphosate and AMPA detection, range of concentrations in runoff samples, and ratios of AMPA to glyphosate concentrations did not vary throughout the growing season as substantially as for other herbicides like atrazine, probably because of different seasonal use patterns. Glyphosate was detected at or above $0.1 \mathrm{\mu g} / \mathrm{l}$ in 35 percent of pre-emergence, 40 percent of post-emergence, and 31 percent of harvest season samples, with a maximum concentration of $8.7 \mathrm{\mu g} / \mathrm{l}$. AMPA was detected at or above $0.1 \mathrm{\mu g} / \mathrm{l}$ in 53 percent of pre-emergence, 83 percent of post-emergence, and 73 percent of harvest season samples, with a maximum concentration of $3.6 \mu \mathrm{g} / \mathrm{l}$. Glyphosate was not detected at a concentration at or above the U.S. Environmental Protection Agency's maximum contamination level (MCL) of $700 \mathrm{\mu g} / \mathrm{l}$ in any sample. Atrazine was detected at or above $0.1 \mu \mathrm{g} / \mathrm{l}$ in 94 percent of pre-emergence, 96 percent of postemergence, and 57 percent of harvest season samples, with a maximum concentration of $55 \mathrm{\mu g} / \mathrm{l}$. Atrazine was detected at or above its MCL ( $3 \mu \mathrm{g} / \mathrm{l})$ in 57 percent of pre-emergence and 33 percent of postemergence samples.

(KEY TERMS: glyphosate; water quality; nonpoint source pollution; herbicides; runoff.)

Battaglin, William A., Dana W. Kolpin, Elizabeth A. Scribner, Kathryn M. Kuivila, and Mark W. Sandstrom, 2005. Glyphosate, Other Herbicides, and Transformation Products in Midwestern Streams, 2002. Journal of the American Water Resources Association (JAWRA) 41(2):323-332.

\section{INTRODUCTION}

\section{Herbicide Chemistry, Use, and Toxicity}

Glyphosate is a nonselective, systemic herbicide that controls most annual and perennial weeds (and other plants) by inhibiting the synthesis of aromatic amino acids needed for protein formation. The use of glyphosate is increasing rapidly, and there is limited understanding of its environmental fate. Glyphosate is highly water soluble and could be mobile in aquatic systems. However, glyphosate binds strongly to cations that are adsorbed to soils (Carlisle and Trevors, 1988). This binding is unlike other organic compounds that primarily adsorb to organic matter in soils. Glyphosate binding is similar to phosphate binding, and it is possible that phosphate accumulation in soils could reduce the capacity for glyphosate binding (Gimsing et al., 2004). The reported organic carbon partition coefficient $\left(\mathrm{K}_{\mathrm{oc}}\right)$ values for glyphosate span several orders of magnitude (Table 1). USDOE (2003) lists the relatively low $\mathrm{K}_{\mathrm{oc}}$ value of 18.8 , while the manufacturer suggests a much higher $\mathrm{K}_{\mathrm{oc}}$ of 24,000 (Monsanto, 2003). It may be difficult to determine reliable physical and chemical property data for some organic compounds (Pontolillo and Eganhouse, 2001). For many organic compounds, low $K_{o c}$ and $K_{o w}$ values imply that limited binding to soils will occur. For glyphosate, however, it appears that binding to soils is not directly to carbon. Glyphosate has low vapor pressure, suggesting that loss to the

\footnotetext{
1Paper No. 04024 of the Journal of the American Water Resources Association (JAWRA) (Copyright (C) 2005). Discussions are open until October 1, 2005.

2Respectively, Hydrologist, U.S. Geological Survey, Box 25046, MS 415, Lakewood, Colorado 80225; Hydrologist, U.S. Geological Survey, P.O. Box 1230, Iowa City, Iowa 52244; Research Assistant, U.S. Geological Survey, 4821 Quail Crest Place, Lawrence, Kansas 66049; Hydrologist, U.S. Geological Survey, Placer Hall, 6000 J Street, Sacramento, California 95819; and Chemist, U.S. Geological Survey, Box 25046, MS 407, Lakewood, Colorado 80225 (E-Mail/Battaglin: wbattagl@usgs.gov).
} 
TABLE 1. Chemical Properties and Drinking Water Standards for Selected Herbicides.

\begin{tabular}{|c|c|c|c|c|c|}
\hline Herbicide & $\begin{array}{c}\text { Water } \\
\text { Solubility } \\
\left(\mathbf{m g} / \mathbf{l} \text { at } 25^{\circ} \mathbf{C}\right)\end{array}$ & $\begin{array}{c}\text { Octanol Water } \\
\text { Partition } \\
\text { Coefficient } \\
\left(\mathbf{K}_{\text {ow }}\right)\end{array}$ & $\begin{array}{c}\text { Organic } \\
\text { Carbon Partition } \\
\text { Coefficient }\left(\mathbf{K}_{\mathbf{o c}}\right) \\
(\mathbf{L} / \mathbf{k g})\end{array}$ & $\begin{array}{l}\text { Vapor Pressure } \\
\left(\mathrm{mm} \mathrm{Hg} \text { at } 25^{\circ} \mathrm{C}\right)\end{array}$ & $\begin{array}{l}\text { EPA Maximum } \\
\text { Contamination } \\
\text { Level (MCL) } \\
\text { or Lifetime } \\
\text { Health Advisory } \\
\text { (HA) in } \mu \mathrm{g} / 1\end{array}$ \\
\hline Acetochlor & 223 & 3.03 & 176.4 & $2.8 \times 10^{-5}$ & 2.0 \\
\hline Alachlor & 148 to 242 & 2.64 to 3.52 & 43 to 209 & $2.1 \times 10^{-5}$ & 2.0 \\
\hline Atrazine & 20 to 35 & 2.34 to 2.80 & 38 to 288 & $2.9 \times 10^{-7}$ & 3.0 \\
\hline Cyanazine & 155 to 170 & 2.02 to 2.24 & 40 to 235 & $1.4 \times 10^{-7}$ & 1.0 \\
\hline Dimethenamid & 1,174 & 2.15 & 155 & $2.7 \times 10^{-4}$ & $*$ \\
\hline Diuron & 42 & 2.68 & 136 to 480 & $6.9 \times 10^{-8}$ & 10 \\
\hline Flufenacet & 56 & 3.20 & $*$ & $2.0 \times 10^{-6}$ & $*$ \\
\hline Glufosinate & $1,370,000$ & -4.81 & 9.6 to 1,229 & $9.1 \times 10^{-12}$ & $*$ \\
\hline Glyphosate & 10,000 to 15,700 & -4.6 to -1.6 & 9 to 60,000 & $4.3 \times 10^{-10}$ & 700 \\
\hline Metolachlor & 488 to 550 & 2.6 to 3.28 & 22 to 307 & $3.1 \times 10^{-5}$ & 100 \\
\hline Metribuzin & 1,000 to 1,220 & 1.6 to 1.7 & 3 to 95 & $4.4 \times 10^{-7}$ & 200 \\
\hline Prometon & 620 to 750 & 2.69 to 2.99 & 32 to 300 & $2.3 \times 10^{-6}$ & 100 \\
\hline Propazine & 3.0 to 8.6 & 2.93 to 3.01 & 100 to 603 & $1.31 \times 10^{-7}$ & 10 \\
\hline Simazine & 3.5 to 84 & 2.10 to 2.18 & 103 to 230 & $2.21 \times 10^{-8}$ & 4 \\
\hline
\end{tabular}

Notes: Water chemistry data from Giesy et al., 2000; EXTOXNET, 2003; USDOE, 2003; or USDA, 2004; MCLs and HAs from USEPA, 2003; *, data not found.

atmosphere from treated surfaces will be small (Table 1).

The half-life of glyphosate and AMPA in aquatic environments is reported to range from 7 to 14 days (Giesy et al., 2000). Glyphosate is degraded primarily by microbial metabolism producing AMPA. (Rueppel et al., 1977), which is structurally similar to the parent herbicide. Aminomethylphosphonic acid is then transformed into carbon dioxide and ammonium. In field dissipation tests, the soil half-life of glyphosate ranged from 2 to 197 days, and the soil half-life for AMPA ranged from 76 to 240 days (Giesy et al., 2000). Glyphosate is a highly polar (charged) molecule, similar in structure to many naturally occurring amino acids, making detection in water samples difficult (Skark et al., 1998; Rubio et al., 2003). Some researchers and the manufacturer suggest that the physical and chemical properties of glyphosate result in a low probability that it will run off from fields, persist in surface water, or leach through soils to ground water (Carlisle and Trevors, 1988; Giesy et al., 2000; Monsanto, 2003). Other researchers suggest that the occurrence and persistence of glyphosate in surface runoff would be similar to that of atrazine (Edwards et al., 1980). Glyphosate is not commonly monitored in current studies that look for large numbers of agricultural chemicals (Larson et al., 1999; Schnoebelen et al., 2003). However, Edwards et al.
(1980) found that glyphosate concentrations in runoff from small ( 0.3 to 3.1 ha) watersheds planted in notill corn or fescue ranged from 2 to $5,153 \mu \mathrm{g} / \mathrm{l}$ and were detected up to four months after application. When compared with atrazine, a herbicide proven to leach and (or) run off during rainfall and persist in surface water (Goolsby and Battaglin, 1993; Battaglin and Goolsby, 1998), glyphosate has much higher solubility in water and a lower vapor pressure but was expected to bind more strongly to soils (Table 1).

Glyphosate is considered to be only slightly toxic to birds, fish, and aquatic invertebrates and is not expected to bioconcentrate (Carlisle and Trevors, 1988; Monsanto, 2003; Oregon State University, 2003). Aminomethylphosphonic acid is considered to be less toxic than glyphosate (Carlisle and Trevors, 1988; Giesy et al., 2000). Several studies have documented that some of the surfactants used in glyphosate formulations are more toxic to wildlife than the glyphosate itself (Martinez and Brown, 1991; Mann and Bidwell, 1999; Tsui and Chu, 2003; Howe et al., 2004); however, the surfactants used in glyphosate products were not included in this study. Glyphosate and its surfactant polyoxyethylene amine (POEA) were more toxic to microalgae and crustaceans than to bacteria and protozoa (Tsui and Chu, 2003). Vision ${ }^{\circledR}$, a glyphosate based forestry herbicide, had variable effects on amphibians when exposed at 
the Canadian expected environmental concentration (ECC) of $1.4 \mathrm{mg} / \mathrm{l}$. One study found "negligible effects" of the herbicide formulation on amphibian larvae when exposed at the ECC (Wojtaszek et al., 2004). Another study reported "significant effects" of the herbicide formulation on amphibians including a statistically significant reduction in survival of adults exposed to one-half the ECC concentration at a $\mathrm{pH}$ of 7.5 (Chen et al., 2004). Glyphosate based herbicide formulations, but not glyphosate alone, caused tail malformations and gonadal abnormalities in tadpoles and frogs at relatively high concentrations $(0.6$ and $1.8 \mathrm{mg} / \mathrm{l}$ ) (Howe et al., 2004). Glyphosate has been recently detected in urine samples from 60 percent of 48 farmers who applied it on their fields and from a small percentage of those farmers' spouses and children (Acquavella et al., 2004). The MCL for glyphosate is $700 \mathrm{\mu g} / \mathrm{l}$ (USEPA, 2003).

Glyphosate was first used in the 1970s and is now among the most common herbicides used for agricultural, silvicultural, and nonagricultural weed control in the world (Woodburn, 2000). The rapid increase in glyphosate use for agriculture (Figure 1) is due to the cultivation of crops that are genetically engineered (Roundup Ready ${ }^{\circledR}$ ) to tolerate this herbicide (Padgette et al., 1995; Giesy et al., 2000). Glyphosate can be used throughout the growing season. It is widely used in no-till agriculture to prepare fields for planting, controlling weeds during crop development, or controlling perennial weeds after crop harvest.

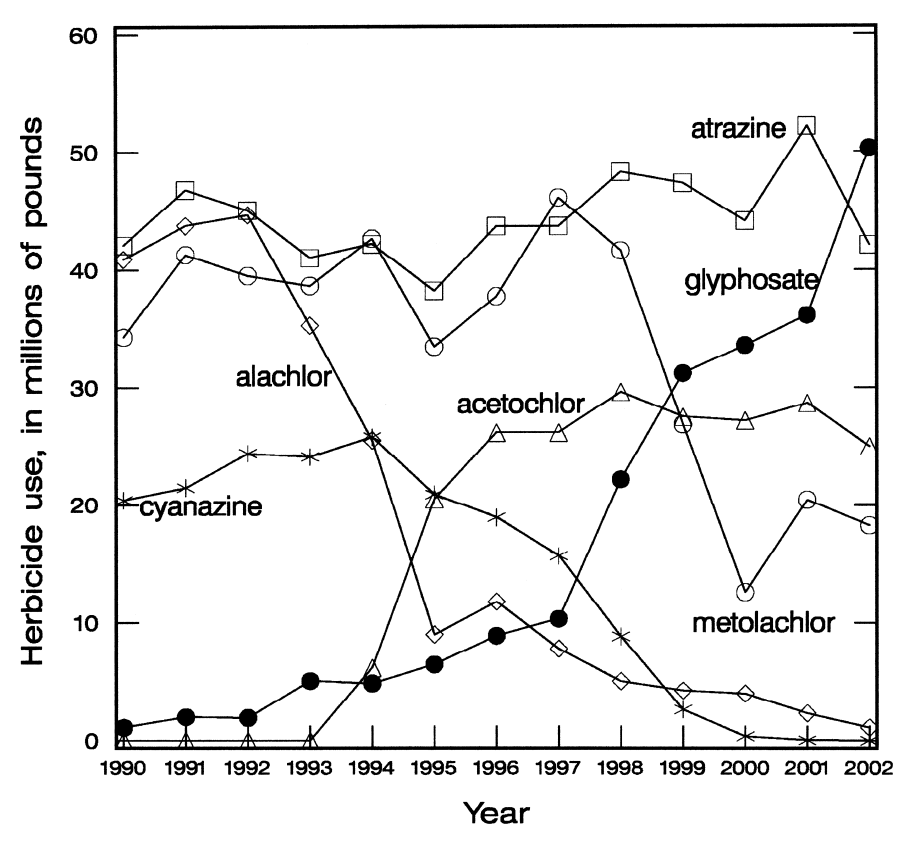

Figure 1. Estimates of Herbicide Use on Crops in Nine Midwestern States (USDA, 2003a, b).
Total herbicide use is one of the most important factors affecting the concentrations of herbicides measured in Midwestern streams (Battaglin and Goolsby, 1999; Scribner et al., 2000). Several substantial changes in herbicide use in the Midwestern United States have occurred over the past decade (Figure 1). Glyphosate use increased from less than five million to more than 50 million pounds per year (USDA, $2003 \mathrm{a}, \mathrm{b})$. Cyanazine production ended in 1999, and sales were discontinued in 2002. Metolachlor production was refined to concentrate the active $\underline{\text { S-isomer }}$ (S-metolachlor), reducing application rates substantially. Acetochlor was introduced in 1993 with its registration contingent on it reducing the use of alachlor and other corn herbicides (USEPA, 1994; Kolpin et al., 1996). From 1998 through 2002 in nine Midwestern states, glyphosate use increased by 127 percent, while acetochlor use decreased by 16 percent, alachlor use decreased by 78 percent, atrazine use decreased by 13 percent, cyanazine use decreased by 100 percent (to zero), and metolachlor use decreased by 56 percent (USDA, 2003a, b).

\section{Objectives and Scope}

The objective of this paper is to document the occurrence of glyphosate and AMPA in Midwestern streams and to compare their occurrence with that of more commonly measured herbicides such as acetochlor, atrazine, and metolachlor and their primary transformation products. It is hypothesized that glyphosate occurrence will differ from these other herbicides due to differences in compound chemistry and application patterns. To accomplish this objective, water samples were collected from Midwestern streams during 2002 and analyzed for the presence of glyphosate and its primary transformation product, AMPA, 20 other herbicides, and 27 other herbicide transformation products.

\section{METHODS}

\section{Sampling Sites, Schedule, Procedures, and Analytical Methods}

In 2002, 51 Midwestern streams were sampled three times each (Figure 2). Most of these sites had been sampled in studies in 1989, 1990, 1994, 1995, and 1998 (Scribner et al., 1993; Battaglin et al., 2001). The timing of sample collection for each site was determined from local crop progress information 
(USDA, 2002), which served as a surrogate for herbicide application information, and local weather conditions. The first samples were collected in May or June after corn was at least 50 percent planted, generally after the application of pre-emergence herbicides such as acetochlor or atrazine, and following precipitation that produced runoff and a measurable increase in streamflow. The second samples were collected in June or July when soybeans were nearing 100 percent emerged, generally after application of postemergence herbicides such as glyphosate and again following precipitation produced runoff. The third samples were collected during or after harvest season (September through November) and again following precipitation produced runoff. At one of the 51 sites (the Eel River near Logansport, Illinois), two postemergence samples were collected on successive days to capture successive runoff events. All water samples were collected using methods described by Edwards and Glysson (1988) and Wilde et al. (1999). Complete details about the study design are provided in Battaglin et al. (2003b) and Scribner et al. (2003).

Water samples were extracted and analyzed by one gas chromatography/mass spectrometry method and four liquid chromatography/mass spectrometry methods. Analyses were completed for 21 herbicides and 27 herbicide transformation products. For complete descriptions of the analytical methods used and resulting data see Lee et al. (2002a, b) and Scribner et al. (2003). For this study, the method reporting limit (MRL) for glyphosate, AMPA, and glufosinate was $0.10 \mu \mathrm{g} / \mathrm{l}$, and the MRL for the other herbicides and transformation products was $0.05 \mu \mathrm{g} / \mathrm{l}$ (Table 2).

Quality control samples consisted of two field blank samples, 14 concurrent replicate samples, and 18 laboratory duplicate samples. The field blank samples were free of herbicides and transformation products. Laboratory duplicate and concurrent replicate

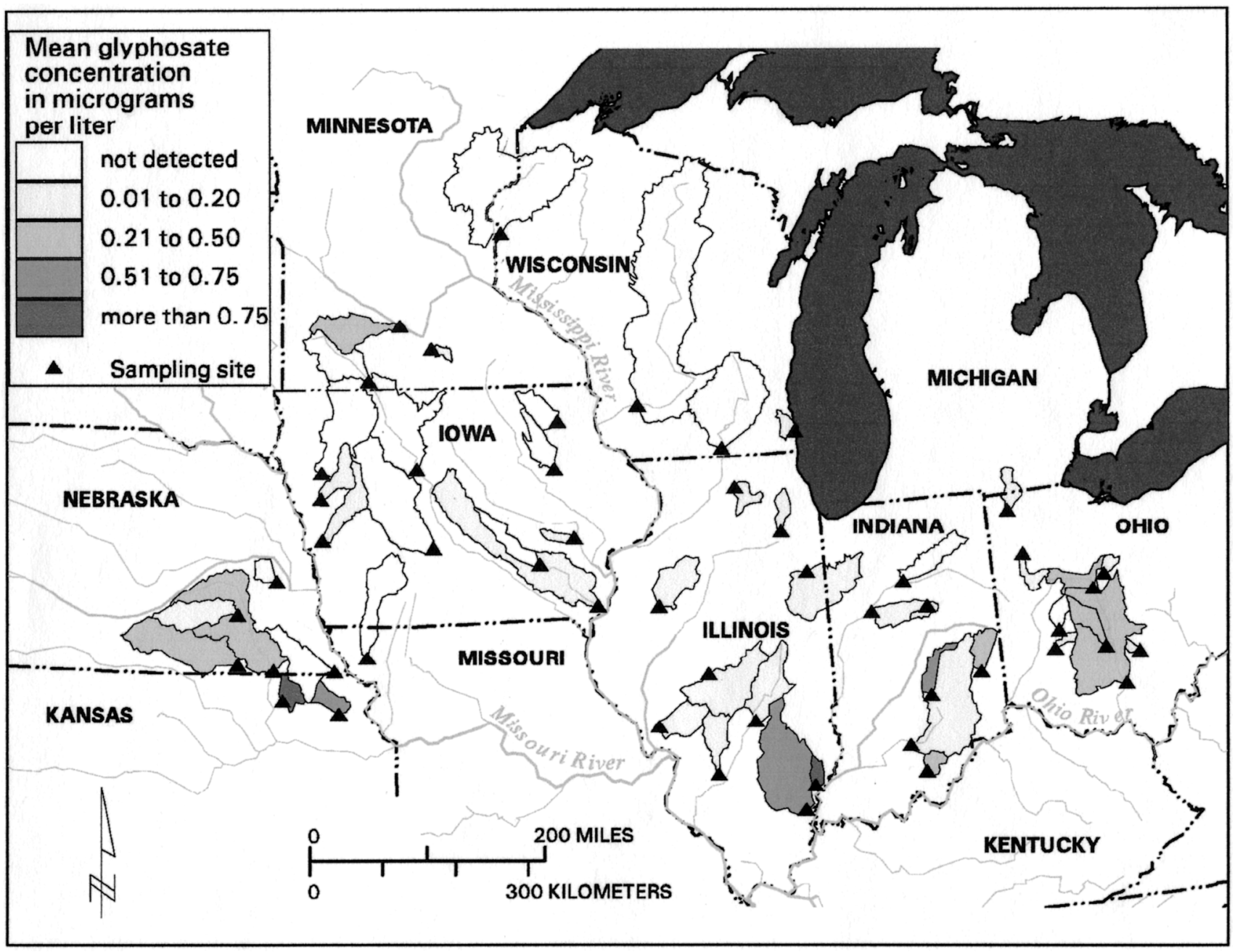

Figure 2. Sampling Sites and Associated Drainage Basins Shaded by the Mean Glyphosate Concentration From the Three Sampling Periods. 
TABLE 2. Decision Frequencies for Selected Herbicides and Herbicide Transformation Products.

\begin{tabular}{|c|c|c|c|c|c|c|c|c|c|c|}
\hline \multirow{2}{*}{$\begin{array}{c}\text { Herbicide or } \\
\text { Transformation } \\
\text { Product }\end{array}$} & \multirow{2}{*}{$\begin{array}{c}\text { Method } \\
\text { Reporting } \\
\text { Limit } \\
\text { (MRL) in } \\
\text { Hg/L }\end{array}$} & \multicolumn{3}{|c|}{$\begin{array}{c}\text { Percent Detections in } \\
\text { Pre-Emergence } \\
\text { Samples Above }\end{array}$} & \multicolumn{3}{|c|}{$\begin{array}{c}\text { Percent Detections in } \\
\text { Post-Emergence } \\
\text { Samples Above }\end{array}$} & \multicolumn{3}{|c|}{$\begin{array}{c}\text { Percent Detections in } \\
\text { Harvest-Season } \\
\text { Samples Above }\end{array}$} \\
\hline & & MRL & $\begin{array}{c}0.1 \\
\mu \mathrm{g} / \mathrm{L}\end{array}$ & $\begin{array}{c}\text { MCL } \\
\text { or HA }\end{array}$ & MRL & $\begin{array}{c}0.1 \\
\mu \mathrm{g} / \mathrm{L}\end{array}$ & $\begin{array}{c}\text { MCL } \\
\text { or HA }\end{array}$ & MRL & $\begin{array}{c}0.1 \\
\mu \mathrm{g} / \mathrm{L}\end{array}$ & $\begin{array}{l}\text { MCL } \\
\text { or HA }\end{array}$ \\
\hline Acetochlor & 0.05 & 90 & 84 & 25 & 58 & 42 & 4 & 16 & 6 & 0 \\
\hline Acetochlor ESA & 0.05 & 94 & 86 & $*$ & 92 & 83 & $*$ & 92 & 71 & $*$ \\
\hline Acetochlor OXA & 0.05 & 94 & 84 & $*$ & 92 & 79 & $*$ & 84 & 65 & $*$ \\
\hline Alachlor & 0.05 & 29 & 22 & 2 & 12 & 10 & 0 & 2 & 2 & 0 \\
\hline Alachlor ESA & 0.05 & 88 & 69 & $*$ & 85 & 60 & $*$ & 96 & 65 & $*$ \\
\hline Alachlor OXA & 0.05 & 37 & 14 & $*$ & 37 & 19 & $*$ & 57 & 10 & $*$ \\
\hline Atrazine & 0.05 & 100 & 94 & 57 & 96 & 96 & 33 & 84 & 57 & 0 \\
\hline Deethylatrazine & 0.05 & 90 & 75 & $*$ & 94 & 81 & $*$ & 76 & 45 & $*$ \\
\hline Deisopropyl-atrazine & 0.05 & 76 & 65 & $*$ & 83 & 71 & $*$ & 45 & 20 & $*$ \\
\hline Hydroxyatrazine & 0.05 & 76 & 55 & $*$ & 92 & 87 & $*$ & 81 & 51 & * \\
\hline Didealkylatrazine & 0.05 & 78 & 69 & $*$ & 79 & 75 & $*$ & 58 & 35 & $*$ \\
\hline Cyanazine & 0.05 & 4 & 0 & 0 & 2 & 0 & 0 & 0 & 0 & 0 \\
\hline Cyanazine amide & 0.05 & 0 & 0 & 0 & $*$ & 0 & $*$ & 0 & 0 & $*$ \\
\hline Dimethenamid & 0.05 & 69 & 57 & $*$ & 40 & 23 & $*$ & 0 & 0 & $*$ \\
\hline Dimethenamid ESA & 0.05 & 55 & 25 & $*$ & 37 & 19 & $*$ & 35 & 8 & $*$ \\
\hline Dimethenamid OXA & 0.05 & 33 & 20 & $*$ & 33 & 12 & $*$ & 14 & 4 & $*$ \\
\hline Flufenacet & 0.05 & 22 & 16 & $*$ & 17 & 13 & $*$ & 2 & 2 & $*$ \\
\hline Glufosinate & 0.10 & 0 & 0 & $*$ & 4 & 4 & $*$ & 0 & 0 & * \\
\hline Glyphosate & 0.10 & 35 & 35 & 0 & 40 & 40 & 0 & 31 & 31 & 0 \\
\hline AMPA & 0.10 & 53 & 53 & $*$ & 83 & 83 & $*$ & 73 & 73 & $*$ \\
\hline Metolachlor & 0.05 & 86 & 82 & 0 & 79 & 63 & 0 & 55 & 31 & 0 \\
\hline Metolachlor ESA & 0.05 & 98 & 98 & $*$ & 94 & 92 & $*$ & 96 & 90 & $*$ \\
\hline Metolachlor OXA & 0.05 & 98 & 90 & $*$ & 94 & 85 & $*$ & 94 & 76 & $*$ \\
\hline Metribuzin & 0.05 & 27 & 24 & 0 & 13 & 8 & 0 & 2 & 2 & 0 \\
\hline Prometon & 0.05 & 8 & 4 & 0 & 15 & 8 & 0 & 6 & 2 & 0 \\
\hline Propazine & 0.05 & 53 & 33 & 0 & 27 & 12 & 0 & 2 & 0 & 0 \\
\hline Simazine & 0.05 & 47 & 33 & 2 & 38 & 20 & 0 & 12 & 8 & 0 \\
\hline
\end{tabular}

Note: $*$ no MCL or HA set.

samples were analyzed to estimate method precision. Concentration differences for each sample pair were calculated as the concentration in the sample minus the concentration in the duplicate, with concentrations that were reported as less than the MRL set to one-half the MRL, which allowed a difference to be calculated when only one of the sample pairs had a reported concentration. For the concurrent replicate samples, the mean of the absolute value of the concentration differences for glyphosate was $0.20 \mathrm{\mu g} / \mathrm{l}$, and the maximum difference was $0.92 \mu \mathrm{g} / \mathrm{l}$. For AMPA, the mean difference was $0.05 \mathrm{mg} / \mathrm{l}$, and the maximum was $0.13 \mathrm{\mu g} / \mathrm{l}$. For the laboratory duplicate samples, the mean of the absolute value of the concentrations differences for glyphosate was $0.03 \mu \mathrm{g} / \mathrm{l}$, and the maximum difference was $0.21 \mathrm{\mu g} / \mathrm{l}$. For AMPA, the mean difference was $0.07 \mu \mathrm{g} / \mathrm{l}$, and the maximum difference was $0.22 \mu \mathrm{g} / \mathrm{l}$.

\section{Statistical Methods}

For all figures and statistics given in this report, nondetects were treated as zero. Substitution of zero for nondetects is likely to produce estimates of mean or median concentration that are biased low (Helsel and Hirsch, 1992). Box plots are used on some figures to show concentration distributions. These box plots show high and low outliers as dots. The central box extends from the 25th to 75th percentile of the data, and the box whiskers extend to the 5th and 95th percentiles. Box plots are truncated at the MRL. The nonparametric Kruskal-Wallis test (Helsel and Hirsch, 1992) is used to test for differences in the distributions of either herbicide concentrations or transformation product to source herbicide concentration ratios from the three sample collection periods. The 
MRL for glyphosate and AMPA $(0.10 \mu \mathrm{g} / \mathrm{l})$ was higher than the MRL for all of the other herbicides and herbicides transformation products $(0.05 \mu \mathrm{g} / \mathrm{l})$, which can affect detection frequency (Kolpin et al., 1994). To aid in the comparison of detection frequencies among herbicides and herbicide transformation products, results are provided using a common MRL concentration of $0.1 \mathrm{\mu g} / \mathrm{l}$.

\section{Estimating Herbicide Use}

Estimates of the use of selected herbicides in 2002 are made by adjusting circa 1997 county level herbicide use estimates (NCFAP, 2003) by the percent change in herbicide use by State between 1997 and 2002 as calculated from U.S. Department of Agriculture (USDA, 2003a, b) data. First, the total use of each herbicide on all crops in each county for circa 1997 is calculated from the National Center for Food and Agricultural Policy data. Then, the percent change in use for each herbicide is calculated for each state as the average of state use in 2001 and 2002 divided by the average of state use in 1997 and 1998 . The percent change estimates are then applied to the circa-1997 use estimates to make 2002 county level use estimates. An area weighted sum algorithm, programmed in a geographic information system (GIS), is used to estimate the amounts of herbicides used in each of the 51 basins associated with the sampling sites. The algorithm accounts for cases where an entire county is within a single drainage basin and cases where only a portion of a county is within a drainage basin. Normalized herbicide use rates are calculated by dividing the herbicide use amounts by drainage basin areas.

\section{RESULTS AND DISCUSSION}

\section{Glyphosate and AMPA}

Glyphosate was detected in 55 of the 154 water samples (36 percent), and its transformation product AMPA was detected in 107 samples (69 percent). Glufosinate, a less commonly used herbicide that is functionally similar to glyphosate, was only detected in two samples. Glyphosate was detected in one or more samples from eight of the nine states, with the exception being Missouri (Figure 2). Highest concentrations, 0.54 to $8.7 \mu \mathrm{g} / \mathrm{l}$, were found in samples from Illinois, Indiana, Kansas, Minnesota, Nebraska, and Ohio, compared to less than 0.10 to $0.46 \mu \mathrm{g} / \mathrm{l}$ in samples from Iowa, Missouri, and Wisconsin. Amino- methylphosphonic acid was detected in one or more samples from all nine states. The highest concentrations, 0.79 to $3.6 \mu \mathrm{g} / \mathrm{l}$, were found in samples from Illinois, Indiana, Kansas, Nebraska, and Ohio, compared to 0.36 to $0.64 \mu \mathrm{g} / \mathrm{l}$ in samples from Iowa, Minnesota, Missouri, and Wisconsin (Scribner et al., 2003). Glyphosate was not detected at or above its MCL of $700 \mathrm{\mu g} / \mathrm{l}$ in any sample, and the maximum concentration measured was approximately 1 percent of its MCL; nor was it detected at a concentration that approached the ECC of $1.4 \mathrm{mg} / \mathrm{l}$. This suggests that the concentrations of glyphosate measured in Midwestern streams in 2002 would not be expected to cause harm to wildlife or aquatic organisms.

For many herbicides, the highest detection frequencies and peak concentrations in streams tend to occur during runoff events that immediately follow herbicide application (Battaglin and Goolsby, 1999). Detection frequencies and ranges of observed herbicide concentrations tend to be much lower in samples collected prior to herbicide application or during harvest season (Goolsby and Battaglin, 1993; Battaglin et al., 2001). For example, atrazine is most commonly applied before the emergence of crops or weeds, and the highest atrazine detection frequency and peak concentrations are expected in the pre-emergence samples. Glyphosate is commonly applied throughout the season because of its use as a pre-plant and postharvest burn down treatment in no-till fields, as well as post-emergence use in glyphosate resistant crops. Hence, the higher detection frequencies and peak concentrations for glyphosate could occur during any of the three sampling periods.

Glyphosate was detected at or above $0.1 \mu \mathrm{g} / \mathrm{l}$ in 35 percent of pre-emergence samples, 40 percent of postemergence samples, and 31 percent of harvest season samples (Table 2 and Figure 3). The distributions of glyphosate concentration in samples from the three periods were not significantly different from each other $(\mathrm{p}=0.41)$. Aminomethylphosphonic acid was detected at or above $0.1 \mathrm{\mu g} / \mathrm{l}$ in 53 percent of preemergence samples, 83 percent of post-emergence samples, and 73 percent of harvest season samples. Aminomethylphosphonic acid was detected at significantly higher concentrations in the post-emergence and harvest season samples than in the preemergence samples $(p=0.002)$. Both AMPA and glyphosate were detected in 35 percent of the 154 samples (all but one of the samples in which glyphosate was detected). Aminomethylphosphonic acid alone was detected in 34 percent of the 154 samples, while neither glyphosate nor AMPA was detected in 30 percent of the samples. The maximum observed glyphosate concentration was $8.7 \mu \mathrm{g} / \mathrm{l}$, and the maximum AMPA concentration was $3.6 \mu \mathrm{g} / \mathrm{l}$. Both of these concentrations were measured in the harvest 
season sample collected from the Black Vermillion River near Frankfort, Kansas.

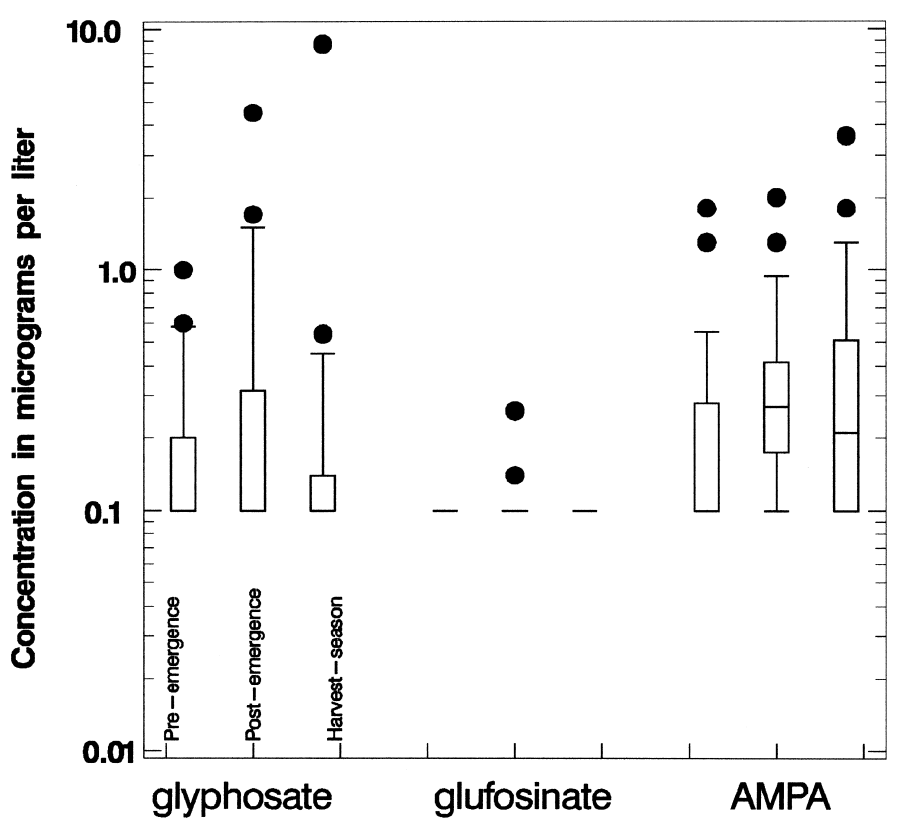

Figure 3. Concentrations of Glyphosate, Glufosinate, and AMPA in Pre-Emergence, Post-Emergence, and Harvest Season Water Samples Collected From 51 Midwestern Streams in 2002.

Ratios of herbicide transformation product concentrations to source herbicide concentrations can be used to estimate environmental fate and transport processes (Thurman and Fallon, 1996; Boyd, 2000; Battaglin et al., 2003a). In general, smaller ratio values are observed in edge of field or soon after application runoff samples and are an indication of being near the herbicide source in either space or time. Larger ratios are more typical in ground water samples and are an indication of being farther from the herbicide source in either space or time. The degradation rates of both source and transformation products in soils and aquatic environments and the number of primary herbicide transformation products can also affect ratio values.

The AMPA-to-glyphosate ratio (AGR) could be calculated for 17 pre-emergence samples, 21 postemergence samples, and 16 harvest season samples. In pre-emergence samples, the AGR ranged from 0.43 to 11.8 , with a median ratio of 0.85 . In postemergence samples, the AGR ranged from 0.20 to 11.8 , with a median ratio of 1.29 . In harvest season samples, the AGR ranged from 0.38 to 6.19 , with a median ratio of 1.87. The distributions of AGR ratios differed from each other by sampling period, but those differences were not statistically significant $(p=0.06)$.
The deethylatrazine-to-atrazine ratios (DAR) were calculated for the same samples used above to calculate AGR values. In pre-emergence samples, the DAR ranged from 0.03 to 0.21 , with a median ratio of 0.07 . In post-emergence samples, the DAR ranged from 0.04 to 0.88 , with a median ratio of 0.26 . In harvest season samples, the DAR ranged from 0.06 to 2.13, with a median ratio of 0.72 . The distributions of DAR ratios differed significantly from each other by sampling period $(\mathrm{p}<0.0001)$. The trend toward increasing DAR values suggests that initially most atrazine enters Midwestern streams quickly via runoff or tile flow, and later in the growing season, ground water becomes a more significant the source of atrazine and deethylatrazine. While the DAR increases by an order of magnitude over the growing season, the AGR only approximately doubles. This suggests that the dominant source of glyphosate was runoff and not ground water even during the harvest season.

Spearman's rank correlations (Helsel and Hirsch, 1992) were used to test the strength of relations between mean concentration of glyphosate and AMPA at the 51 sites, and the use of glyphosate in the associated drainage basins. Mean concentrations of glyphosate (Figure 2) and AMPA are calculated as the simple average of the concentrations from the three samples collected at each site. The correlation coefficient between mean glyphosate concentration and glyphosate use (0.19) was not significant $(p=0.18)$. Mean AMPA concentrations were more strongly correlated with glyphosate use $(0.41, \mathrm{p}=0.003)$. The sum of the mean glyphosate and AMPA concentrations were also significantly correlated $(0.34, \mathrm{p}=0.014)$ with glyphosate use. Hence there was some association between use of glyphosate and occurrence of glyphosate and/or AMPA in Midwestern rivers, but that correlation was not as strong as has been observed for other herbicides like atrazine (Battaglin and Goolsby, 1997).

\section{Other Herbicides and Herbicide Transformation Products}

In the pre-emergence runoff samples, four herbicides were detected at or above $0.1 \mu \mathrm{g} / \mathrm{l}$ at least as frequently as glyphosate (Table 2). Acetochlor was detected in 84 percent of samples; atrazine was detected in 94 percent of samples; dimethenamid was detected in 57 percent of samples; and metolachlor was detected in 82 percent of samples. In the postemergence runoff samples, three herbicides were detected at or above $0.1 \mathrm{\mu g} / \mathrm{l}$ at least as frequently as glyphosate (Table 2). Acetochlor was detected in 42 percent of samples; atrazine was detected in 96 percent of samples; and metolachlor was detected in 63 
percent of samples. In the harvest season runoff samples, only two herbicides were detected at or above 0.1 $\mu \mathrm{g} / \mathrm{l}$ at least as frequently as glyphosate (Table 2). Atrazine was detected in 57 percent of samples; and metolachlor, like glyphosate, was detected in 31 percent of samples. For all six herbicides shown in Figure 4, there is a marked decrease in detection frequency and the measured concentrations between the pre-emergence samples and the post-emergence and harvest season samples. These six compounds all tend to be applied prior to the emergence of crops and weeds, although atrazine can also be applied before corn reaches 12 inches $(30.5 \mathrm{~cm})$ in height (Syngenta, 2004).

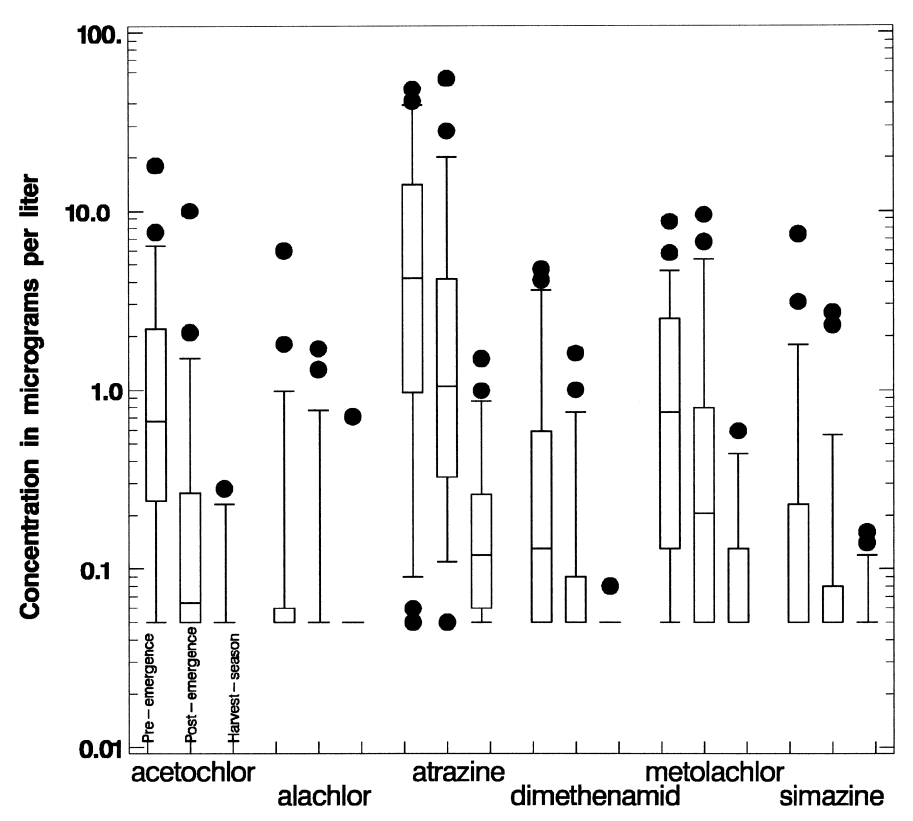

Figure 4. Concentrations of Acetochlor, Alachlor, Atrazine, Dimethenamid, Metolachlor, and Simazine in Pre-Emergence, Post-Emergence, and Harvest Season Water Samples Collected From 51 Midwestern Streams in 2002.

In prior study years, cyanazine was also detected in more than 75 percent of pre-emergence samples, with median concentrations ranging from $0.44 \mu \mathrm{g} / \mathrm{l}$ in 1998 to $2.6 \mathrm{\mu g} / \mathrm{l}$ in 1989 (Scribner et al., 2000). However, the registrants of cyanazine ended production in 1999, and existing stock sales ended in 2002. Cyanazine was only detected in two pre-emergence samples from 2002, with a maximum concentration of $0.08 \mathrm{\mu g} / \mathrm{l}$. The rapid disappearance of cyanazine and its transformation products (Scribner et al., 2003) from Midwestern streams indicates that the source of these chemicals to streams during runoff conditions is predominantly due to current year applications and not inputs from prior years or ground water sources (Battaglin et al., 2003a).

Several other herbicides were detected at concentrations that exceeded their MCLs or lifetime health advisory (HA) levels (Tables 1 and 2). Atrazine exceeded its MCL of $3 \mu \mathrm{g} / \mathrm{l}$ in 57 percent of preemergence samples and 33 percent of post-emergence samples. The maximum atrazine concentration detected was approximately 18 times larger than its MCL. Acetochlor exceeded its MCL of $2 \mu \mathrm{g} / \mathrm{l}$ in 25 percent of pre-emergence samples and 4 percent of postemergence samples. The maximum acetochlor concentration was approximately nine times larger than its MCL. Alachlor exceeded its MCL of $2 \mu \mathrm{g} / \mathrm{l}$ in a single (2 percent) pre-emergence sample, and simazine exceeded its MCL of $4 \mathrm{\mu g} / \mathrm{l}$ in a single (2 percent) pre-emergence sample.

In the pre-emergence runoff samples, nine herbicide transformation products were detected at or above $0.1 \mathrm{\mu g} / \mathrm{l}$ at least as frequently as AMPA (Table 2). Acetochlor ESA and OXA, alachlor ESA, metolachlor ESA and OXA, deethylatrazine, deisopropylatrazine, didealkylatrazine, and hydroxyatrazine were all detected in 53 percent or more of the 51 samples. In the post-emergence runoff samples, four herbicide transformation products were detected at or above 0.1 $\mu \mathrm{g} / \mathrm{l}$ at least as frequently as AMPA (Table 2). Acetochlor ESA, metolachlor ESA and OXA, and hydroxyatrazine were all detected in 83 percent or more of the 52 samples. In the harvest season runoff samples, only two herbicide transformation products were detected at or above $0.1 \mu \mathrm{g} / \mathrm{l}$ at least as frequently as AMPA (Table 2). Metolachlor ESA and OXA were detected in more than 73 percent of the 51 samples. Some of these other herbicide transformation products may be more mobile in the environment than AMPA, but historically heavy use (Figure 1) may also contribute to their prevalence in Midwestern streams.

Glyphosate was detected in surface water samples from many Midwestern streams. Because these water samples all passed through a $0.7 \mathrm{~mm}$ pore size filter prior to analysis, the glyphosate was not adsorbed to sediment, though it could be adsorbed to colloidal material (Speth, 1993). The frequency of glyphosate and AMPA detection, the range of observed concentrations in runoff samples, and the ratios of AMPA to glyphosate concentration did not differ throughout the growing season as substantially as for the other herbicides. This may be explained by differences in use patterns and fate and transport factors. Glyphosate is used throughout the growing season for control of existing weeds, while the other herbicides tested are more commonly applied before the emergence of crops or weeds. Other herbicides with similar use patterns, like nicosulfuron, which is applied post-emergence, and imazethapyr, which can 
be applied either pre-emergence or post-emergence, showed a similar pattern of occurrence in pre-emergence and post-emergence samples (Battaglin et al., 2001). Glyphosate can persist for a long time in the soils or sediment, where it may remain susceptible to mobilization after rainfall. Reported soil halflife(lives) for glyphosate ranged from days to months (Carlisle and Trevors, 1988; Giesy et al., 2000; USDA, 2004) and were in part dependent on the level of soil microbial activity. Glyphosate is also commonly used in urban settings and along highways, so there is the potential for an urban or point source signature (Huang et al., 2004). Although some conventional drinking water treatments such as activated carbon filtration, chlorine, and ozone seem to eliminate glyphosate, other treatments more common in primary sewage treatments such as settling and filtration may not (Speth, 1993). Glyphosate was detected twice as frequently in urban streams downstream from wastewater treatment plants than upstream of those plants (Kolpin et al., 2005).

Although glyphosate and (or) AMPA were found in many samples, other herbicides with similar or less total use in the Midwestern United States, such as acetochlor, atrazine, and metolachlor (Figure 1), were often detected more frequently and at higher concentrations (Table 2, Figures 3 and 4). It is probable that glyphosate is not as mobile and is transformed more rapidly in the environment than these other herbicides (Table 1). However, it also appears that glyphosate and AMPA are more mobile or persistent in aquatic environments than earlier research and monitoring suggest (Giesy et al., 2000). Additional monitoring for glyphosate and AMPA to include summer low flow and wintertime samples could provide the information needed to determine which use, fate, and transport factors have the most influence on their environmental occurrence. Additional monitoring will be needed to determine if the increasing use of glyphosate results in increasing glyphosate and AMPA concentrations in Midwestern streams.

\section{LITERATURE CITED}

Acquavella, J.F., B.H. Alexanders, J.S. Mandel, C. Gustin, B. Baker, P. Chapman, and M. Bleeke, 2004. Glyphosate Biomonitoring for Farmers and Their Families: Results From the Farm Family Exposure Study. Environmental Health Perspectives 112(3):321-326.

Battaglin, W.A., E.T. Furlong, M.R. Burkhardt, and L.L. Boyer, 2001. Concentrations of Selected Sulfonylurea, Sulfonamide, and Imidazolinone Herbicides, and Other Pesticides in Storm Runoff From 71 Streams, Outflow From 5 Reservoirs, and Ground Water From 25 Wells in the Midwestern United States, 1998. U.S. Geological Survey Water-Resources Investigations Report 00-4225, 123 pp., Reston, Virginia.
Battaglin, W.A. and D. A. Goolsby, 1997. Statistical Modeling of Agricultural Chemical Occurrence in Midwestern Rivers. Journal of Hydrology 196:1-25.

Battaglin, W.A. and D.A. Goolsby, 1998. Regression Models of Herbicide Concentrations in Outflow From Reservoirs in the Midwestern USA, 1992-1993. Journal of the American Water Resources Association (JAWRA) 34(6):1369-1390.

Battaglin, W.A. and D.A. Goolsby, 1999. Are Shifts in Herbicide Use Reflected in Concentration Changes in Midwestern Rivers? Environmental Science and Technology 33:2917-2925.

Battaglin, W.A., E.M. Thurman, S.J. Kalkhoff, and S.D. Porter, 2003a. Herbicides and Transformation Products in Surface Waters of the Midwestern United States. Journal of the American Water Resources Association (JAWRA) 39(4):743-756.

Battaglin, W.A., E.M. Thurman, D.W. Kolpin, E.A. Scribner, M.W. Sandstrom, and K.M. Kuivila, 2003b. Work Plan for Determining the Occurrence of Glyphosate, Its Transformation Product AMPA, Other Herbicide Compounds, and Antibiotics in Midwestern United States Streams, 2002. U.S. Geological Survey Open-File Report 03-69, 18 pp. Reston, Virginia.

Boyd, R.A., 2000. Herbicides and Herbicide Degradates in Shallow Ground Water and the Cedar River Near a Municipal Well Field, Cedar Rapids, Iowa. The Science of the Total Environment 248: 241-253.

Carlisle, S.M. and J.T. Trevors, 1988. Glyphosate in the Environment. Water, Air, and Soil Pollution 39:409-420.

Chen, Y.C., K.M. Hathaway, and C.L. Folt, 2004. Multiple Stress Effects of Vision Herbicide, $\mathrm{pH}$, and Food on Zooplankton and Larval Amphibian Species From Forest Wetlands. Environmental Toxicology and Chemistry 23(4):823-831.

Edwards, T.K. and D.G. Glysson, 1988. Field Methods for Measurement of Fluvial Sediment. U.S. Geological Survey Open-File Report 86-531, 118 pp. Reston, Virginia.

Edwards, W.M., G.B. Triplett, Jr., and R.M. Kramer, 1980. A Watershed Study of Glyphosate Transport in Runoff. Journal of Environmental Quality 9(4):661-665.

Giesy, J.P., S. Dobson, and K.R. Solomon, 2000. Ecotoxicological Risk Assessment for Roundup Herbicide. Reviews of Environmental Contamination and Toxicology 167:35-120.

Gimsing, A.L., O.K. Borggaard, and P. Sestoft, 2004. Modeling the Kinetics of the Competitive Adsorption and Desorption of Glyphosate and Phosphate on Goethite and Gibbsite and in Soils. Environmental Science and Technology 38:1718-1722.

Goolsby, D.A. and W.A. Battaglin, 1993. Occurrence, Distribution, and Transport, of Agricultural Chemicals in Surface Waters of the Midwestern United States. In: Selected Papers on Agricultural Chemicals in Water Resources of the Midcontinental United States, Donald Goolsby (Editor). U.S. Geological Survey Open-File Report 93-418, pp. 1-24, Reston, Virginia.

Helsel, D.R. and R.M. Hirsch, 1992. Statistical Methods in Water Resources. Elsevier, New York, New York, 552 pp.

Howe, C.M., M. Berrill, B.D. Pauli, C.C. Helbing, K. Werry, and N. Veldhoen, 2004. Toxicity of Glyphosate-Based Pesticides to Four North American Frog Species. Environmental Toxicology and Chemistry 23(8):1928-1934.

Huang, X., T. Pedersen, M. Fischer, R. White, and T. Young, 2004. Herbicide Runoff Along Highways - 1. Field Observations. Environmental Science and Technology 38:3263-3271.

Kolpin, D.W., M.R. Burkart, and E.M. Thurman, 1994. Herbicides and Nitrate in Near-Surface Aquifers in the Midcontinental United States, 1991. U.S. Geological Survey Water-Supply Paper 2413, 34 pp., Reston, Virginia.

Kolpin, D.W., D.A. Goolsby, and E.M. Thurman, 1996. Acetochlor in the Hydrologic System in the Midwestern United States, 1994. Environmental Science and Technology 30:1459-1464. 
Kolpin, D.W., E.M. Thurman, E.A. Lee, M.M. Meyer, E.T. Furlong, and S.T. Glassmeyer, 2005. Urban Contributions of Glyphosate and Its Degradates AMPA to Streams in the United States. The Science of the Total Environment.

Larson, S.J., R.J. Gilliom, and P.D. Capel, 1999. Pesticides in Streams of the United States - Initial Results From the National Water-Quality Assessment Program. U.S. Geological Survey Water-Resources Investigations Report 98-4222, 99 pp., Reston, Virginia.

Lee, E.A., A.P. Strahan, and E.M. Thurman, 2002a. Methods of Analysis by the U.S. Geological Survey Organic Geochemistry Research Group - Determination of Glyphosate, Aminomethylphosphonic Acid, and Glufosinate in Water Using Online SolidPhase Extraction and High Performance Liquid Chromatography/Mass Spectrometry. U.S. Geological Survey Open-File Report 01-454, 13 pp., Reston, Virginia.

Lee, E.A., A.P. Strahan, and E.M. Thurman, 2002b. Methods of Analysis by the U.S. Geological Survey Organic Geochemistry Research Group - Determination of Triazine and Phenylurea Herbicides and Their Degradation Products in Water Using Online Solid-Phase Extraction and Liquid Chromatography/ Mass Spectrometry. U.S. Geological Survey Open-File Report 02436, 19 pp., Reston, Virginia.

Mann, R.M. and J.R. Bidwell, 1999. The Toxicity of Glyphosate and Several Glyphosate Formulations to Four Species of Southwestern Australian Frogs. Archives of Environmental Contaminant Toxicology 36:193-199.

Martinez, T.T. and K. Brown, 1991. Oral and Pulmonary Toxicology of the Surfactant Used in Roundup Herbicide. Proceeding of the Western Pharmacological Society 34:43-46.

Monsanto, 2003. Backgrounder - Glyphosate and Environmental Fate Studies. Monsanto, St. Louis, Missouri, 4 pp.

NCFAP (National Center for Food and Agricultural Policy), 2003. National Pesticide Use Database. National Center for Food and Agricultural Policy. Available at http://www.ncfap.org/database/ default.htm. Accessed on December 15, 2003.

Oregon State University, 2003. Pesticide Information Profiles (PIPs). EXTOXNET: The Extension Toxicology Network. Available at http://extoxnet.orst.edu/pips/ghindex.html. Accessed on November 20, 2003.

Padgette, S.R., K.H. Kolacz, and X. Delannay, 1995. Development, Identification, and Characterization of a Glyphosate-Tolerant Soybean Line. Crop Science 35:1451-1461.

Pontolillo, J. and R.P. Eganhouse, 2001. The Search for Reliable Aqueous Solubility (Sw) and Octanol-Water Partition Coefficient (Kow) Data for Hydrophobic Organic Compounds: DDT and DDE As a Case Study. U.S. Geological Survey Water Resources Investigations Report 01-4201, 55 pp., Reston, Virginia.

Rubio, F., L.J. Veldhuis, B.S. Clegg, J.R. Fleeker, and J.C. Hall, 2003. Comparison of a Direct ELISA and an HPLC Method for Glyphosate Determinations in Water. Journal of Agricultural and Food Chemistry 51:691-696.

Rueppel, M.L., B.B. Brightwell, J. Schaefer, and T.T. Marvel, 1977. Metabolism and Degradation of Glyphosate in Soil and Water. Journal of Agricultural and Food Chemistry 25:517-528.

Schnoebelen, D.J., S.J. Kalkhoff, K.D. Becher, and E.M. Thurman, 2003. Water-Quality Assessment of the Eastern Iowa Basins: Selected Pesticides and Pesticide Degradates in Streams, 199698. U.S. Geological Survey Water-Resources Investigations Report 03-4075, 62 pp., Reston, Virginia.

Scribner, E.A., W.A. Battaglin, J.E. Dietze, and E.M. Thurman, 2003. Reconnaissance Data for Glyphosate, Other Selected Herbicides, Their Degradation Products, and Antibiotics in 51 Streams in Nine Midwestern States, 2002. U.S. Geological Survey Open-File Report 03-217, 101 pp., Reston, Virginia.

Scribner, E.A., W.A. Battaglin, D.A. Goolsby and E.M. Thurman, 2000. Changes in Herbicide Concentrations in Midwestern
Streams in Relation to Changes in Use, 1989-1998. The Science of the Total Environment 248:255-263.

Scribner, E.A., E.M. Thurman, D.A. Goolsby, M.T. Meyer, M.S. Mills, and M.L. Pomes, 1993. Reconnaissance Data for Selected Herbicides, Two Atrazine Degradation Products, and Nitrate in Surface Water of the Midwestern United States, 1989-90. U.S. Geological Survey Open-File Report 93-457, 77 pp., Reston, Virginia.

Skark, C., N. Zullei-Seibert, U. Schottler, and C. Schlett, 1998. The Occurrence of Glyphosate in Surface Water. International Journal of Environmental Analytical Chemistry 70(1-4):93-104.

Speth, T.F., 1993. Glyphosate Removal From Drinking Water. Journal of Environmental Engineering 119(6):1139-1157.

Syngenta, 2004. New! Information for Relabeling Atrazine Products. Available at http://www.syngentacropprotection-us.com/ $\mathrm{prod} /$ herbicide/Atrazine/. Accessed in September 2004.

Thurman, E.M. and J.D. Fallon, 1996. The Deethylatrazine/ Atrazine Ratio as a Indicator of the Onset of the Spring Flush of Herbicides Into Surface Water of the Midwestern United States. International Journal of Environmental Analytical Chemistry 65:203-214.

Tsui, Martin T.K. and L.M. Chu, 2003. Aquatic Toxicity of Glyphosate-Based Formulation: Comparison Between Different Organisms and the Effects of Environmental Factors. Chemosphere 52:1189-1197.

USDA (U.S. Department of Agriculture), 2002. 2002 Crop Progress and Weekly Weather and Crop Bulletin. National Agricultural Statistics Service (NASS). Available at http://usda.mannlib. cornell.edu/reports/nassr/field/weather/2002/. Accessed on AprilJuly, 2002.

USDA (U. S. Department of Agriculture), 2003a. Agricultural Chemical Use Database. National Agricultural Statistics Service (NASS). Available at http://www.pestmanagement.info/ nass/. Accessed on December 12, 2003.

USDA (U. S. Department of Agriculture), 2003b. Agricultural Chemical Usage - 2002 Field Crops Summary. U.S. Department of Agriculture, National Agricultural Statistics Service (NASS), Washington, D.C., 102 pp.

USDA (U. S. Department of Agriculture), 2004. The ARS Pesticide Properties Database (PPDB). Agricultural Research Service. Available at http://www.arsusda.gov/acsl/services/ppdb/. Accessed on March 12, 2004.

USDOE (U.S. Department of Energy), 2003. Chemical-Specific Factors. Risk Assessment Information System. Available at http://risk.lsd.ornl.gov/cgi-bin/tox/TOX_select?select=csf. Accessed on November 24, 2003.

USEPA (U.S. Environmental Protection Agency), 1994. Questions and Answers - Conditional Registration of Acetochlor. Available at http://www.epa.gov/oppefed1/aceto/qsandas.htm. Accessed on March 8, 2004.

USEPA (U.S. Environmental Protection Agency), 2003. 2002 Edition of the Drinking Water Standards and Health Advisories. EPA 822-R-02-038, Office of Water, USEPA, Washington, D.C., $12 \mathrm{pp}$.

Wilde, F.D., D.B. Radtke, J. Gibs, and R.T. Iwatsubo (Editors), 1999. National Field Manual for the Collection of Water-Quality Data. U.S. Geological Survey Techniques of Water-Resources Investigations, Book 9, Chapter A. Available at http://water.usgs.gov/ owq/FieldManual/. Accessed on April 5, 2002.

Wojtaszek, B.F., B. Staznik, D.T. Chartrand, G.R. Stephenson, and D.G. Thompson, 2004. Effects of Vision Herbicide on Mortality, Avoidance Response, and Growth of Amphibian Larvae in Two Forest Wetlands. Environmental Toxicology and Chemistry 23(4):832-842.

Woodburn, A., 2000. Glyphosate: Production, Pricing, and Use Worldwide. Pesticide Management Science 56:309-312. 